\title{
One-step synthesis of a singly bridged biscalix[6]arene and evaluation of its alkali metal recognition properties
}

\author{
Abha Naveen Kumar $^{1 * \oplus}$, Jayshree Ramkumar ${ }^{2 \oplus,}$ \\ S. Chandramouleeswaran ${ }^{2 \oplus}$ and Sandip Kumar Nayak ${ }^{1 \oplus}$ \\ ${ }^{1}$ Bio-Organic Division, Bhabha Atomic Research Centre, Trombay, Mumbai 400085, India \\ ${ }^{2}$ Analytical Chemistry Division,Bhabha Atomic Research Centre, Trombay, Mumbai 400085, India
}

(Received June 24, 2017; Revised September 28, 2017; Accepted October 2, 2017)

\begin{abstract}
This article describes one-step synthesis of a singly bridged biscalix[6]arene (2) and evaluation of its recognition properties towards alkali metal ions for the first time. Synthesis of 2 was accomplished through coupling of two 4-tert-butylcalix[6] arene units with one molecule of diethyleneglycol ditosylate. Both base and linker were found to play a role in the outcome of coupling reaction for the simple and efficient synthesis of 2. Complexation ability of 2 was studied by liquid-liquid extraction using alkali metal $\left(\mathrm{Na}^{+}, \mathrm{K}^{+}, \mathrm{Cs}^{+}\right)$picrates. Carrier activity of $\mathbf{2}$ towards the facilitated transport of alkali metal ions across a bulk liquid membrane was also studied and the transport behaviour was mechanistically explained. The predominant role of an ion exchange action mechanism in the transport process was observed.
\end{abstract}

Keywords: Biscalix[6]arene; singly bridged; bulk liquid membrane transport; alkali metal ions. (C) 2017 ACG Publications. All rights reserved.

\section{Introduction}

Design and synthesis of biscalixarenes is an interesting aspect of calixarene chemistry ${ }^{1,2}$ since it provides multifunctional spaces for guest complexation ${ }^{3}$ and can display high-level host properties such as cooperativity and/or allosteric effects. ${ }^{4,5}$ For example, biscalixarenes joined via tail-to-tail linkage provide two diverging cavities and have been utilized for the formation of polycaps, ${ }^{6}$ as redoxactive ionophores ${ }^{7}$ and ditopic receptors ${ }^{8}$ etc.

Earlier, our research group members have demonstrated the synthesis ${ }^{9,10}$ and application ${ }^{11-16}$ of various calixarenes as hosts in selective complexation with different guests such as cesium ion, ${ }^{11,12}$ fullerenes ${ }^{13-15}$ as well as in transportation of uranyl ion across a liquid membrane. ${ }^{16}$ Inspired by the report of Haino et al. on the complexation of singly bridged biscalix[5]arenes with large guests such as $\mathrm{C}_{60}$ and $\mathrm{C}_{70},{ }^{17,18}$ we previously synthesized a novel singly bridged biscalix[6]arene (2) and studied its supramolecular interaction with fullerenes. ${ }^{19}$ During the course of this work, we found that the synthesis of 2 from 4-tert-butylcalix[6]arene (1) according to the reported methods was truly cumbersome.

\footnotetext{
${ }^{*}$ Corresponding author: E-mail: abha@barc.gov.in Phone: +912225590232 Fax: +912225505151
} 
The literature survey revealed that the number of reports available for the synthesis of singly bridged biscalix[6]arenes linked via their lower rims, is quite limited. In one such report, Gutsche and co-workers prepared two biscalix[6]arenes employing diyne and $p$-xylylene spanners in three and two steps starting from 1, respectively, in overall yields of $34 \%$ and $8 \%$, respectively. ${ }^{20}$ Due to the presence of six chemically similar phenolic-OH groups in 1, many of the synthetic methods suffer from multiple steps of protection/deprotection of the similar phenolic functions prior to the intermolecular coupling to accomplish singly bridged biscalixarenes. ${ }^{20-22}$ As an example, Neri and coworkers reported the synthesis of a $m$-xylylene spacered biscalix[6]arene in overall yield of $10 \%$ from calix[6]arene in four steps. ${ }^{22}$ Therefore, there is much demand to develop an efficient methodology for the synthesis of singly bridged biscalix[6]arenes.

So far, reports on the syntheses of singly bridged biscalix[6]arenes are very limited and accordingly their ionophoric properties have not been studied in depth. In continuation of our efforts in the development of calixarene based ionophores for selective extraction of useful metal ions, herein we report a practically convenient one-step synthesis of a singly bridged biscalix[6]arene 2 from $\mathbf{1}$. Also the ionophoric behavior of $\mathbf{2}$ towards alkali metal ions has been investigated.

\section{Experimental}

All the reagents are of analytical grade and were used as received. Reactions were conducted under argon atmosphere using freshly dried solvents. Melting points were recorded on a Fisher-Johns melting point apparatus and are uncorrected. The FT-IR spectra were scanned by a Jasco model A-202 FT-IR spectrophotometer. ${ }^{1} \mathrm{H}$ and ${ }^{13} \mathrm{C}$ NMR spectra in $\mathrm{CDCl}_{3}$ were recorded by a Bruker $\mathrm{AC} 200$ spectrometer at ambient temperature. $J$ values are given in $\mathrm{Hz}$. The multiplicities of the signals in the ${ }^{1} \mathrm{H}$ NMR spectra are abbreviated by s (singlet), $\mathrm{d}$ (doublet), $\mathrm{t}$ (triplet), q (quartet), $\mathrm{m}$ (multiplet), br (broad) and combinations thereof. FAB mass spectrum of 2 was recorded on a Jeol SX 102/Da-600 mass spectrometer using $m$-nitrobenzyl alcohol as the matrix. Mass spectral data of $\mathbf{3}$ was obtained by a micromass-Q-TOF (YA-105) spectrometer. Metal ion solutions $(0.1 \mathrm{M})$ were prepared by dissolving appropriate amounts of their chloride salts in de-ionized water. The membrane phase solutions were prepared in chloroform (E. Merck) and diluted further with the same solvent. The $\mathrm{pH}$ measurements of the aqueous phase were performed using an EIL $7030 \mathrm{pH}$ meter (India) equipped with a combination electrode. The metal ion concentrations were determined using a HITACHI 180-80 polarized Zeeman atomic absorption spectrometer. The carrier concentration measurement and the recording of their electronic spectra were conducted using a Shimadzu 210A UV-Visible double beam spectrophotometer.

\subsection{Chemistry}

\subsubsection{General Procedure for Synthesis of Calix[6] arene Based Hosts (2) and(3):}

A mixture of 4-tert-butyl calix[6]arene (1) $(5.00 \mathrm{~g}, 5.1 \mathrm{mmol})$ and $\mathrm{KHCO}_{3}(0.82 \mathrm{~g}, 8.2 \mathrm{mmol})$ in $\mathrm{CH}_{3} \mathrm{CN}(100 \mathrm{~mL})$ was refluxed for 3 hours. The mixture was cooled to room temperature and the appropriate ditosylate $(3.1 \mathrm{mmol})$ was added and the mixture was further refluxed for 7 days. After removal of the solvent under vacuo, the residue was quenched with water, acidified with aq. $1 \mathrm{~N} \mathrm{HCl}$, and extracted with $\mathrm{CHCl}_{3}$. The organic layer was washed with water, brine, and dried (anhydrous $\mathrm{Na}_{2} \mathrm{SO}_{4}$ ). Solvent was removed and the residue was purified by column chromatography over silica gel $\left(\mathrm{CH}_{2} \mathrm{Cl}_{2} /\right.$ hexane $)$ to obtain pure 2 and $\mathbf{3}$.

Bis [2-(5,11,17,23,29,35-hexa-tert-butyl-37,38,39,40,41-pentahydroxy-42-calix[6]arenyloxy)ethyl]

ether $(2)^{19}$ : Following the above mentioned procedure using diethyleneglycol ditosylate $(1.28 \mathrm{~g}, 3.1$ $\mathrm{mmol})$ as the ditosylate, $\mathbf{2}$ was isolated as a white solid (1.44 g, 28\% yield) along with unreacted $\mathbf{1}$ (2.55 g, 51\% left). M. P. $216-218^{\circ} \mathrm{C}$. IR $\left(\mathrm{CHCl}_{3}\right) \vee\left(\mathrm{cm}^{-1}\right): 3216,2957,2867,1754,1603,1484,1362$, 1293, 1244, 1202, 871, 758. ${ }^{1} \mathrm{H}$ NMR (200 MHz, $\left.\mathrm{CDCl}_{3}\right) \delta(\mathrm{ppm}): 1.15$ (s, 18H), $1.19(\mathrm{~s}, 18 \mathrm{H}), 1.24$ 
$(\mathrm{s}, 36 \mathrm{H}), 1.28(\mathrm{~s}, 36 \mathrm{H}), 3.38-3.60(\mathrm{~m}, 12 \mathrm{H}), 4.02(\mathrm{t}, J=15.1 \mathrm{~Hz}, 8 \mathrm{H}), 4.42-4.52(\mathrm{~m}, 12 \mathrm{H}), 6.97(\mathrm{~s}$, $4 \mathrm{H}), 7.04-7.14(\mathrm{~m}, 20 \mathrm{H}), 8.98(\mathrm{~s}, 4 \mathrm{H}), 9.61(\mathrm{br} \mathrm{s}, 2 \mathrm{H}), 9.85(\mathrm{~s}, 4 \mathrm{H}) .{ }^{13} \mathrm{C}$ NMR $\left(50 \mathrm{MHz}, \mathrm{CDCl}_{3}\right) \delta$ (ppm): $31.2,31.4,31.6,32.2,32.5,33.3,33.6,33.9,34.2,71.9,75.7,125.3,125.8,126.2,126.5,126.8$, $126.9,127.4,132.5,142.8,143.5,144.2,146.7,147.8,148.1,149.3,149.4$. FAB-MS: $m / z: 2017$ $[\mathrm{M}+2 \mathrm{H}]^{+}$. Anal. Calcd. for $\mathrm{C}_{136} \mathrm{H}_{174} \mathrm{O}_{13}: \% \mathrm{C}, 80.99 ; \mathrm{H}, 8.70$. Found: $\mathrm{C}, 80.80 ; \mathrm{H}, 8.56$.

5,11,17,23,29,35-Hexa-tert-butyl-37,38,40,41-tetrahydroxycalix[6] arene-39,42-(crown-4) (3) Following the above mentioned procedure using triethyleneglycol ditosylate $(1.42 \mathrm{~g}, 3.1 \mathrm{mmol})$ as the ditosylate, 3 was isolated as a white solid ( $1.55 \mathrm{~g}, 28 \%$ yield) along with the starting material 1 (2.46 g, 49\% left). M. P. $256-258{ }^{\circ} \mathrm{C}$ (lit. ${ }^{23}$ M. P. $\left.258{ }^{\circ} \mathrm{C}\right)$. IR $\left(\mathrm{CHCl}_{3}\right) \vee\left(\mathrm{cm}^{-1}\right): 3361,2959,2871,1483$, 1362, 1293, 1202, 1119. ${ }^{1} \mathrm{H}$ NMR $\left(200 \mathrm{MHz}, \mathrm{CDCl}_{3}\right) \delta(\mathrm{ppm}): 1.13(\mathrm{~s}, 18 \mathrm{H}), 1.28(\mathrm{~s}, 36 \mathrm{H}), 3.52(\mathrm{~m}$, $6 \mathrm{H}), 4.06-4.12(\mathrm{~m}, 10 \mathrm{H}), 4.22(\mathrm{~s}, 4 \mathrm{H}), 4.39(\mathrm{~m}, 4 \mathrm{H}), 6.98(\mathrm{~s}, 4 \mathrm{H}), 7.12(\mathrm{br} \mathrm{s}, 8 \mathrm{H}) .{ }^{13} \mathrm{C} \mathrm{NMR}(50 \mathrm{MHz}$, $\left.\mathrm{CDCl}_{3}\right) \delta(\mathrm{ppm}): 31.2,31.6,32.1,32.8,33.9,34.2,69.2,70.2,125.4,125.8,125.9,127.0,127.7,132.1$, 142.6, 147.6, 149.6, 150.1. HRMS $\left(\mathrm{ESI}^{+}\right): \mathrm{m} / \mathrm{z}$ calcd. for $\mathrm{C}_{72} \mathrm{H}_{95} \mathrm{O}_{8}[\mathrm{M}+\mathrm{H}]^{+}: 1087.7027$, found 1087.3715. Anal. Calcd. for $\mathrm{C}_{72} \mathrm{H}_{94} \mathrm{O}_{8}: \%$ C, 79.52; H, 8.71. Found: $\mathrm{C}, 79.40 ; \mathrm{H}, 8.59$.

\subsection{Ionophoric Behaviour}

\subsubsection{Extraction of Alkali Metal Picrates by Biscalix[6]arene (2)}

The alkali picrates were prepared by stepwise addition of an aqueous solution of picric acid to the aqueous solutions of metal hydroxides of known concentration, until neutralization $(\mathrm{pH}$ monitoring). The precipitates were rapidly washed with ethanol and diethyl ether, and dried in vacuo for $24 \mathrm{~h} .{ }^{24}$ Extraction of alkali metal picrates from their solutions in deionized water into chloroform was conducted according to the following typical procedure: $10 \mathrm{ml}$ of aqueous metal picrate solution $(5 \mathrm{mM})$ was equilibrated with $10 \mathrm{ml}$ of biscalix[6]arene 2 solution in chloroform $(1 \mathrm{mM})$ for a period of $3 \mathrm{~h}$ at ambient temperature. The concentration of picrate ion remaining in the aqueous phase, was then determined spectrophotometrically as described in the literature. ${ }^{25}$ Each experimental result reported is the arithmetic mean of four independent measurements. Blank experiments showed that in the absence of calixarene there was no extraction of the alkali metal picrate into the organic phase.

\subsubsection{Bulk Liquid Membrane Transport of Alkali Metal Ions by Biscalix[6]arene (2)}

The transport experiments were carried out using a set-up as shown in Figure $1 .^{26}$

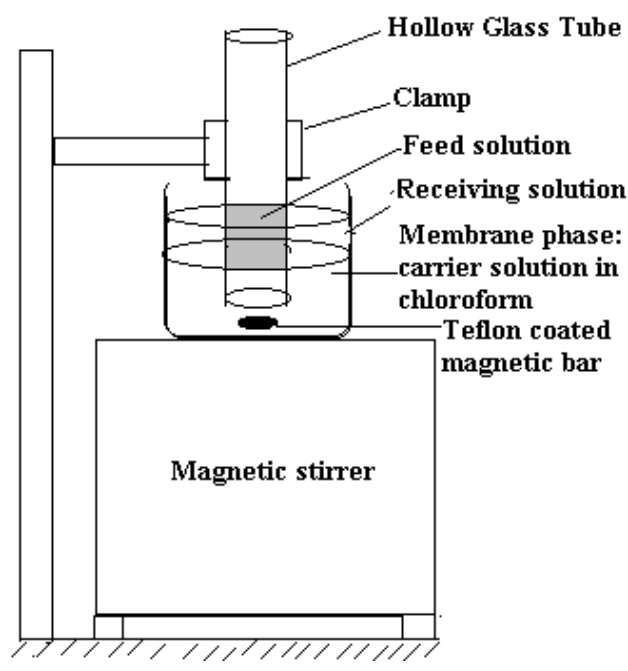

Figure 1. Experimental set-up for bulk liquid membrane transport 
All the experiments were performed under ambient temperature. In a typical experiment, the volumes of the feed and receiving phases were kept at $10 \mathrm{~mL}$ and $25 \mathrm{~mL}$, respectively. The bulk membrane consisting of chloroform solution $(50 \mathrm{~mL})$ of the carrier compounds was placed at the bottom of a glass beaker (height $8 \mathrm{~cm}$ and i.d.7 cm). A glass cylindrical tube (i.d. $2.3 \mathrm{~cm}$ ) open at both the ends was suspended vertically $1 \mathrm{~cm}$ above the bottom of the beaker and well below the surface of chloroform membrane. Feed solution consisting of metal salt solution $(10 \mathrm{~mL}, 0.1 \mathrm{M})$ was placed carefully on top of the chloroform layer inside the cylinder. Receiving solution consisting of aqueous hydrochloric acid solution $(25 \mathrm{~mL}, 0.1 \mathrm{M})$ was placed atop the outer ring of chloroform. The organic phase was stirred with a magnetic stirrer for $24 \mathrm{~h}$. Each experimental result reported is the average of three independent determinations.

\section{Results and Discussion}

\subsection{Chemistry}

Synthesis of singly bridged biscalix[6]arenes, connected via lower rim, necessarily involve coupling of two molecules of mono-phenolate of $\mathbf{1}$ with one molecule of a bifunctional linker. To this end, the real challenge remains in selective preparation of mono-phenoxyl anion of $\mathbf{1}$ in the presence of six chemically equivalent hydroxyl functionalities present in 1. Earlier, we demonstrated that regioselective mono-alkylation of $\mathbf{1}$ with a variety of electrophiles could be accomplished using $\mathrm{K}_{2} \mathrm{CO}_{3}$ as a base. ${ }^{9}$ Keeping this in view, we envisaged that it might be possible to synthesize singly bridged biscalix[6]arene 2 from 1 using diethyleneglycol ditosylate as an electrophile and $\mathrm{K}_{2} \mathrm{CO}_{3}$ as a base. But, this reaction led to a complex array of products. In the light of this observation and some of our unpublished results, we envisaged that generation of monoanion of 1 might be more feasible with milder base like $\mathrm{KHCO}_{3}$ under refluxing conditions. Fortuitously in this case, the reaction of 1 with diethyleneglycol ditosylate afforded desired singly bridged biscalix[6]arene $\mathbf{2}$ in modest yield (28\%) along with unreacted $\mathbf{1}(51 \%)$ (Scheme 1). Compound $\mathbf{2}$ was easily purified by column chromatography, and characterized by spectral data (IR, ${ }^{1} \mathrm{H} \mathrm{NMR},{ }^{13} \mathrm{C} \mathrm{NMR}$, mass) and elemental analysis. Its ${ }^{1} \mathrm{H}-\mathrm{NMR}$ spectral data showed four signals at $\delta 1.15,1.19,1.24$ and 1.28 ppm (ratio $1: 1: 2: 2$ ) for tert-butyl protons, and three signals at $\delta 8.98,9.61$ and 9.85 ppm (ratio 2:1:2) for hydroxyl protons (Figure S1, Supplementary information). Signals for methylene protons are observed in the region of $\delta 3.38-4.52 \mathrm{ppm}$ and signals in the region of $\delta 6.97-7.14 \mathrm{ppm}$ are assigned to aromatic protons. ${ }^{13} \mathrm{C}$ NMR spectrum of 2 shows two resonances for carbon of the $\mathrm{OCH}_{2}$ group at $\delta 71.9$ and $75.7 \mathrm{ppm}$ (Figure S2). The carbons of the aromatic rings are observed as a set of sixteen resonances over the chemical shift range of $\delta$ 125.3-149.4 ppm. Its structure was further confirmed by elemental analysis and mass spectral data (Figure S3).

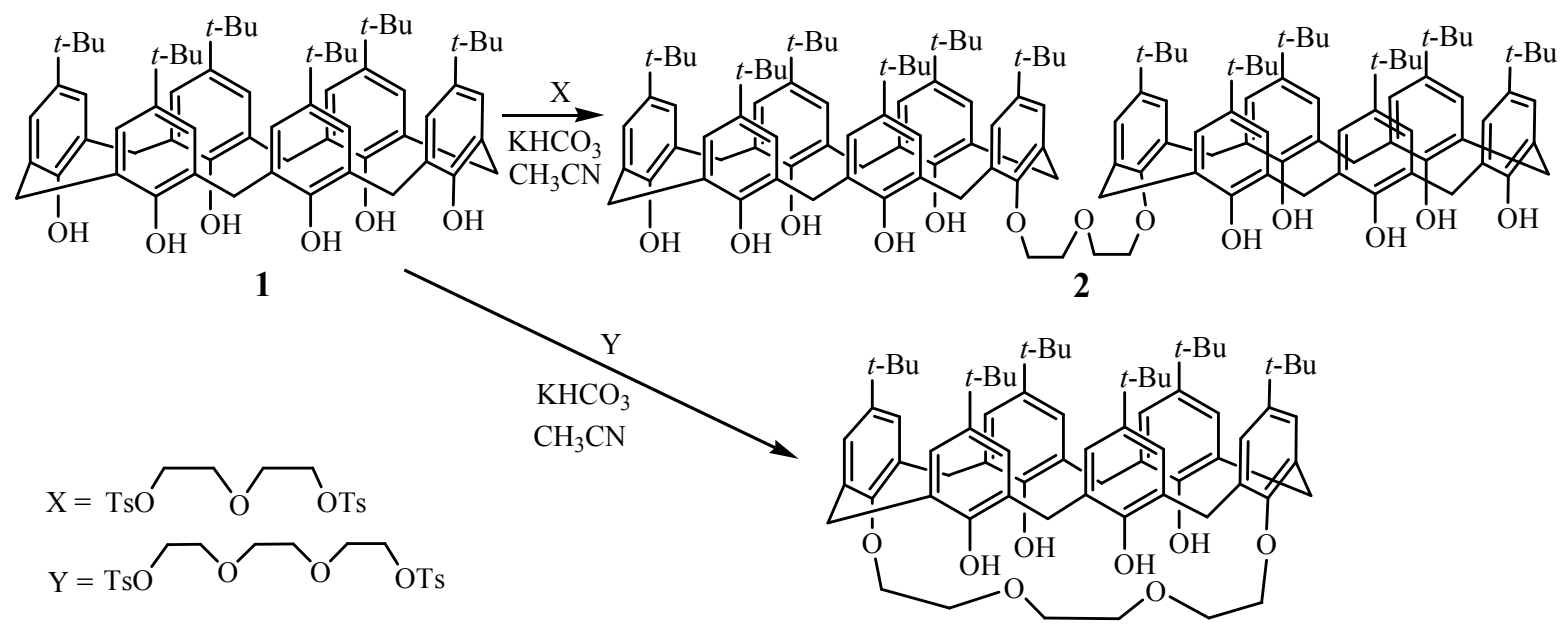

Scheme 1. Synthesis of compounds 2 and 3 
Being a single step procedure, this is a very simple and practically convenient method to obtain 2. In addition to that, above finding is quite significant since calixcrowns are generally formed by direct reaction of $\mathbf{1}$ with oligoethylenglycol ditosylates. As an example, there is no mention of formation of singly bridged biscalix[6]arenes like 2 in any of these literature reports ${ }^{23,27-38}$ studying reaction of 1 with oligoethylenglycol ditosylates.

To further improve the yields of $\mathbf{2}$, other bases $\left(\mathrm{K}_{2} \mathrm{CO}_{3}, \mathrm{KHCO}_{3}-\mathrm{K}_{2} \mathrm{CO}_{3}\right.$ and $\left.\mathrm{Cs}_{2} \mathrm{CO}_{3}\right)$ were also employed. Disappointingly, all the reactions using these bases $\left[\mathrm{K}_{2} \mathrm{CO}_{3}, \mathrm{KHCO}_{3}-\mathrm{K}_{2} \mathrm{CO}_{3}(1: 1)\right.$ and $\mathrm{Cs}_{2} \mathrm{CO}_{3}$ ] led to the formation of a complex mixture of compounds. Therefore, use of $\mathrm{KHCO}_{3}$ as a base remained a good choice for the synthesis of biscalix[6]arene (2) in high purity with easy purification, simply by column chromatography.

Interestingly, using triethyleneglycol ditosylate as an electrophile under identical reaction conditions (Scheme 1), led to the formation of calix[6]arene-crown-4 (3) in 28\% yield. Compound 3 was fully characterized by spectral (IR, ${ }^{1} \mathrm{H},{ }^{13} \mathrm{C}$, mass) and analytical data. Assignment of the calixcrown formation was performed unambiguously by its ${ }^{1} \mathrm{H}$ NMR spectra. Its ${ }^{1} \mathrm{H}-\mathrm{NMR}$ spectral data showed two singlets at $\delta 1.13$ and $1.28 \mathrm{ppm}$ for tert-butyl protons in a 1:2 intensity ratio, and two signals at $\delta 6.98$ and $7.12 \mathrm{ppm}$ for the aromatic protons (Figure S4). ${ }^{13} \mathrm{C}$ NMR spectrum of 3 shows two resonances for carbon of the $\mathrm{OCH}_{2}$ group at $\delta 69.2$ and $70.2 \mathrm{ppm}$ (Figure S5). The carbons of the aromatic rings are observed as a set of ten resonances over the chemical shift range of $\delta$ 125.4-150.1 ppm. Its elemental composition was further confirmed by data obtained from elemental analysis and mass spectrum (Figure S6). Furthermore, melting point and spectral data of $\mathbf{3}$ matches well with the reported spectral data leaving no further ambiguity. ${ }^{23}$ This result is in line with the literature reports enlisting the direct coupling reaction of oligoethyleneglycol ditosylates with $1 .^{23,27-38}$

Thus, both base and linker play a role in the outcome of coupling reaction to accomplish the desired synthesis of singly bridged biscalix[6]arene like 2 .

\subsection{Extraction Behaviour of 2}

In this report, we have also checked alkali metal complexation properties of biscalixarene $\mathbf{2}$, since these are not yet reported in the literature. To check the alkali metal ion recognition behavior of compound 2, initially extraction studies were conducted using the alkali metal ( $\mathrm{Na}, \mathrm{K}, \mathrm{Cs}$ ) picrates. The results are presented in Table 1, which revealed that the compound 2 is more selective for the $\mathrm{K}^{+}$ and can discriminate between the alkali metal ions.

Table 1. Percentage extraction (E \%) of alkali metal picrates from deionized water into $\mathrm{CHCl}_{3}$ with the compound $\mathbf{2}^{\mathrm{a}}$

\begin{tabular}{ccccc}
\hline \multirow{2}{*}{ Compound } & \multicolumn{3}{c}{ \% Extraction $^{\mathbf{b}}$} \\
\cline { 2 - 4 } & $\mathbf{N a}^{+}$ & $\mathbf{K}^{+}$ & $\mathbf{C s}^{+}$ \\
\hline $\mathbf{2}$ & 10.2 & 25.6 & 5.2 \\
$\mathbf{3}^{\mathbf{c}}$ & 6.5 & 4.5 & 10.2 \\
\hline
\end{tabular}

a aqueous phase, $10 \mathrm{~mL}$, [metal picrate] $=5 \mathrm{mM}$; organic phase, $10 \mathrm{~mL}$, chloroform, [compound] $=1 \mathrm{mM}$; equilibration time $=3$

${ }^{b}$ arithmetic mean of four independent measurements. Values with uncertainties less than

${ }^{c}$ these data are quoted from reference 32 .

Since biscalixarene 2 showed significant extraction of alkali metal picrates from aqueous to organic phase, it prompted us to examine its carrier activity towards transport of alkali metal ions across a bulk liquid membrane as membrane transport of alkali metal ions has significant applications in wide variety of fields ranging from biological, chemical to analytical sciences. 


\subsection{Transport Behaviour of 2}

The membrane transport studies were conducted using chloride salts of all the metal ions. The transport experiments were performed using a set-up shown in Figure 1, which is based on the concept of Schulman Bridge. ${ }^{39}$ Two aqueous phases, namely feed and receiving phases, were spatially separated by chloroform layer, which acts as a membrane phase. All the experiments were carried out under ambient temperature conditions. In a typical experiment, feed solution and receiving phase solutions consisted of metal salt solution and aqueous hydrochloric acid solution, respectively. The bulk membrane consisting of chloroform solution of the calixarene compounds was placed at the bottom of the beaker. Feed solution was placed on top of the chloroform layer inside the cylinder, and the receiving phase solution was placed atop the outer ring of chloroform. Blank experiments showed that in the absence of calixarene compounds $\mathbf{2}$ and $\mathbf{3}$, there was no transport of the metal ion across the membrane. Each experimental result reported is the average of three independent determinations. Initially, for membrane transport studies, deionized water was used as a receiving solution. But, in that case, no transport of metal ions was observed. Since metal ions used in these studies were in their chloride salt forms, $\mathrm{HCl}$ was used as a receiving phase. In an earlier study by our group using calixarenes as carriers for membrane transport studies, it was observed that an increase in the acidity of the receiving solution increased the extent of bleeding. But, a decrease in the acidity of the receiving phase reduced the permeation rate. ${ }^{16}$ Variation of acidity showed that optimum acidity was $0.1 \mathrm{M}$ and thus, in this study, all the experiments were carried out using $0.1 \mathrm{M} \mathrm{HCl}$ as the receiving phase.

In an earlier study by our group using calixarenes as carriers for membrane transport studies, it was observed that variation of the $\mathrm{pH}$ of the feed solution revealed low permeation at low $\mathrm{pH}$, which increased with increase of $\mathrm{pH}$, and calixarenes were found to be good extractants at neutral or alkaline $\mathrm{pH} .{ }^{16}$ In this study, all the transport experiments were carried out using solutions of the metal chlorides at $\mathrm{pH} \sim 8$, and concentration of the carriers in the membrane was maintained as $10^{-4} \mathrm{M}$.

The results of single ion transport of alkali metal ions by compounds $\mathbf{2}$ and $\mathbf{3}$ after a period of 24 $\mathrm{h}$ under the optimized experimental conditions are given in Table 2 . The concentration profiles are described in terms of transport flux calculated for a period of $24 \mathrm{~h}$. The results also give a clear picture of carrier activity of both the compounds $\mathbf{2}$ and $\mathbf{3}$ towards alkali $\left(\mathrm{Na}^{+}, \mathrm{K}^{+}, \mathrm{Cs}^{+}\right)$ions. Coupled with the uphill transport, a degree of selectivity of the carriers for different metal ions was observed. Since the experiments were conducted for a single ion transport, the word "selectivity" actually denotes the amount of metal ions transported during a fixed period of time $(24 \mathrm{~h})$. Table 2 shows that the order of transport flux rates for alkali metal ions for compound $\mathbf{2}$ is $\mathrm{K}^{+}>\mathrm{Cs}^{+}>\mathrm{Na}^{+}$and for $\mathbf{3}$, it is $\mathrm{Na}^{+}>\mathrm{K}^{+}>\mathrm{Cs}^{+}$.

Table 2. Single ion transport values of metal ions through a bulk liquid membrane using carriers $\mathbf{2}$ and $\mathbf{3}^{\mathrm{a}}$

\begin{tabular}{|c|c|c|}
\hline \multirow{2}{*}{ Metal ions } & \multicolumn{2}{|c|}{ 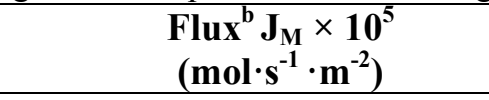 } \\
\hline & 2 & 3 \\
\hline $\mathrm{Na}^{+}$ & 1.7 & 9.4 \\
\hline $\mathbf{K}^{+}$ & 12 & 0.29 \\
\hline $\mathrm{Cs}^{+}$ & 2.9 & 0.077 \\
\hline
\end{tabular}

${ }^{a}$ transport conditions: feed phase (aqueous solution of metal chloride at $\mathrm{pH} \sim 8,10 \mathrm{~mL}$ ), $[\mathrm{MCl}]=0.1 \mathrm{M}$; membrane phase $\left(\mathrm{CHCl}_{3}, 50 \mathrm{~mL}\right.$ ), [carrier] $=10^{-4} \mathrm{M}$; receiving phase (aqueous $\mathrm{HCl}$ solution, $25 \mathrm{~mL}$ ), $[\mathrm{HCl}]=0.1 \mathrm{M}$; time $=24 \mathrm{~h}$.

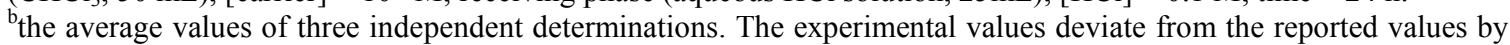
an average of $10 \%$.

It was observed that the $\mathrm{pH}$ of the feed solution gradually decreased while that of the receiving phase increased. The transport involves a net transfer of metal ions from the feed to the receiving phase and an equivalent amount of $\mathrm{H}^{+}$in the opposite direction, where ratio of moles of metal ions 
transported $/ \mathrm{H}^{+}$transported $=1 / 1$ as revealed by the measurement of $\mathrm{H}^{+}$concentration in the source phase. Thus, a coupled transport mechanism involving ion exchange was inferred. A schematic representation of the transport mechanism for transport of metal ion across a bulk liquid membrane is shown in Scheme 2, where the bulk liquid membrane contains compounds $\mathbf{2}$ or $\mathbf{3}$ as the carriers for transportation of metal ions. The overall mechanism can considered as a four-step process: Step 1, at the organic membrane phase-alkaline aqueous feed phase interface, the carrier is deprotonated and forms a complex with the metal cation, which results in the release of an equivalent amount of proton to the feed solution. The selectivity of the calixarene host $(\mathrm{CH})$ for $\mathrm{M}^{+}$is expressed and $\mathrm{M}^{+} \mathrm{C}^{-}$is extracted into the organic membrane phase as a complex. Step 2, the electroneutral complex $\mathrm{M}^{+} \mathrm{C}^{-}$then diffuses across the organic membrane. Step 3, at the organic membrane phase-acidic aqueous receiving phase interface, the acid present in the receiving side stripped out the metal ion from the complex $\mathrm{M}^{+} \mathrm{C}^{-}$by protonating the carrier. The metal cation is released into the receiving solution. Step 4 , the free carrier which is now in the electroneutral form $(\mathrm{CH})$, diffuses back across the organic membrane to begin another cycle at the membrane-feed interface. Transport of the metal ion is continued till concentration of metal ion is too low to form complex with the carrier. Therefore, the net result is transport of the metal ion from the feed aqueous phase to the receiving aqueous phase coupled with counter-transport of a proton.

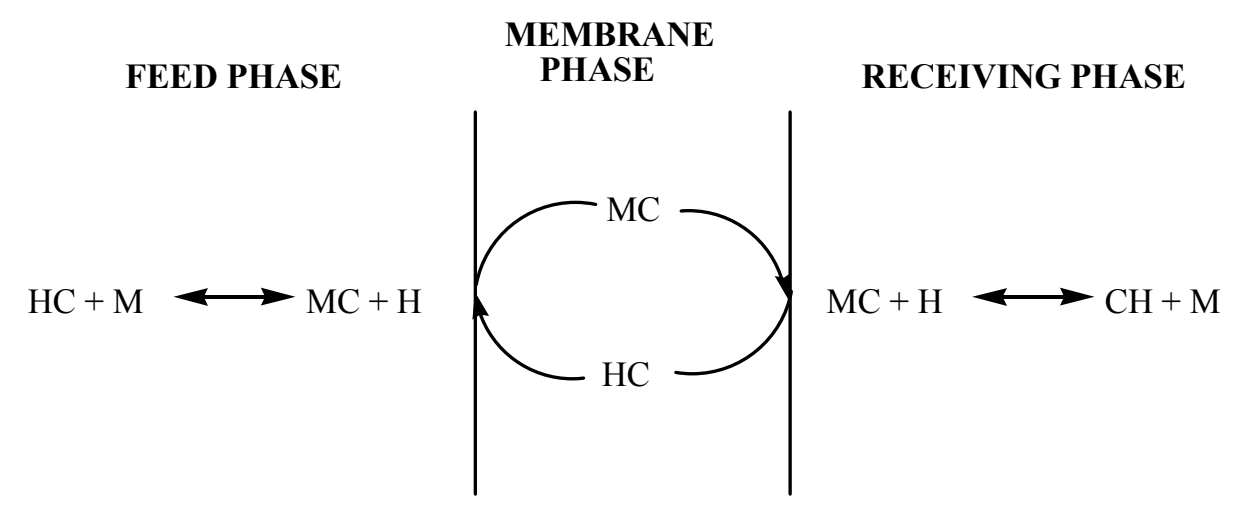

Scheme 2. Schematic representation of mechanism of the transport process

Deprotonation of the phenolic groups of the carriers was also confirmed by comparing the UV-visible spectra of the chloroform solutions of the carriers prior to and after treatment with base (Figure 2). UV-visible spectra of the chloroform solution of the carriers are shown in Figure 2a. Compound 2 showed two absorption maxima at 230 and $275 \mathrm{~nm}$ whereas compound 3 showed a strong absorption maximum at $234 \mathrm{~nm}$. However, after equilibration of organic solutions of the carriers with $0.1 \mathrm{M} \mathrm{NaOH}$ for $24 \mathrm{~h}$, the UV-visible spectra changed significantly (Figure $2 \mathrm{~b} v$ s Figure 2a).

After treatment with base, both compounds $\mathbf{2}$ and $\mathbf{3}$ showed only one maxima at 290 and 280 $\mathrm{nm}$, respectively (Fig. 2b). These changes in the spectral features are attributed to the deprotonation of these compounds during equilibration with $\mathrm{NaOH}$. The extracts were then treated with $0.1 \mathrm{M} \mathrm{HCl}$, equilibrated with fresh chloroform, and the spectra were recorded (Fig. 2c). It was observed that the spectra were identical to the spectra of the carriers before their treatment with base, suggesting regeneration of the parent compounds. These observations coupled with the decrease of the $\mathrm{pH}$ of the feed solution, not only confirm the deprotonation of the carriers $\mathbf{2}$ and $\mathbf{3}$, but also the reversibility of the deprotonation-protonation reaction.

Ion exchange mechanism of transport for metal ions across the membrane was further confirmed by using solutions of picrate salts of the metal ions as the feed solution. Although transport of the colored picrate anions to the receiving compartment was not visually or spectrophotometrically observed even after carrying out the transport experiment for more than $24 \mathrm{~h}$, the transport of the cations was confirmed from the measurements of their concentrations. Thus, ion-exchange mechanism 
was found to be the operating mechanism for the transport of alkali metal ions across a bulk liquid membrane using $\mathbf{2}$ and $\mathbf{3}$ as the carriers.
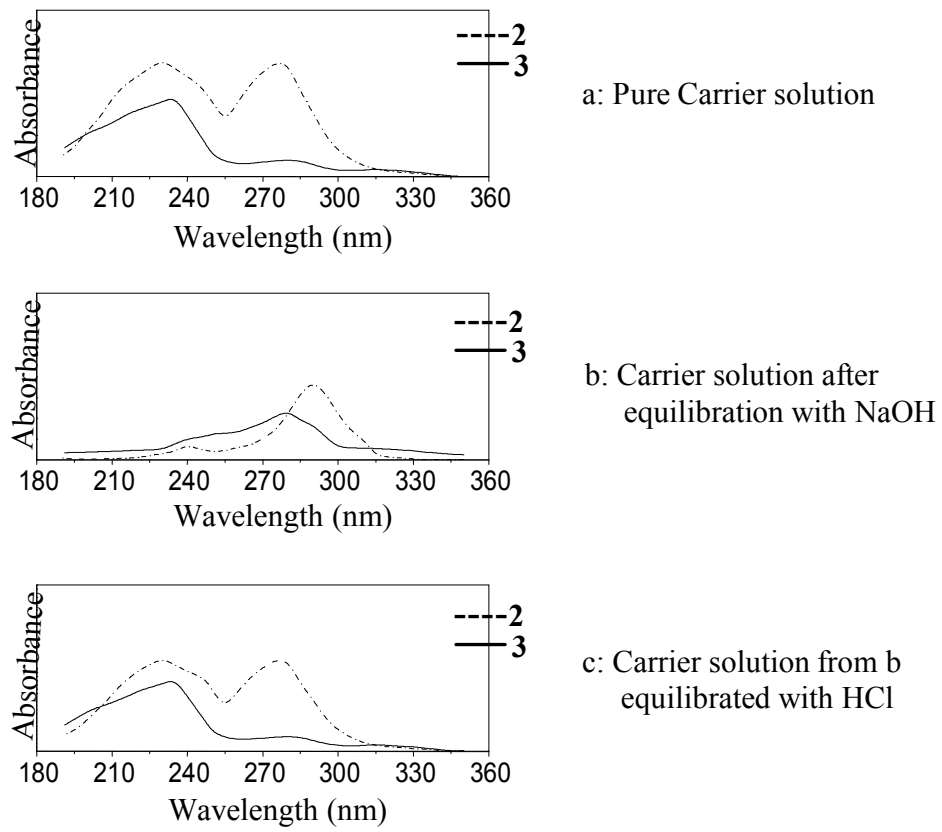

Figure 2a-c. UV spectra of the solution of carriers $\mathbf{2}$ and $\mathbf{3}$ in $\mathrm{CHCl}_{3}$ after different treatments

\section{Conclusion}

In conclusion, for the first time one-step synthesis of singly bridged biscalix[6]arene $\mathbf{2}$ from $\mathbf{1}$ has been accomplished in $28 \%$ yield with high purity, in a simple and practically convenient method by using $\mathrm{KHCO}_{3}$ as a base and dietheyleneglycol ditosylate as an electrophile. This is an important finding since direct coupling of oligoethyleneglycol ditosylates with $\mathbf{1}$ is known to invariably yield calixcrowns in the literature, ${ }^{23,27-38}$ without any mention of generation of singly bridged biscalixarenes like 2 in any of these reports.

The exotic structural arrangement in biscalix[6]arene $\mathbf{2}$ prompted us to study its ionophoric activity against alkali metal ions both by solvent extraction and membrane transport. Ion-exchange mechanism was found to be the operating mechanism for the transport process. Further work on exploring various aspects of the above findings is currently underway.

\section{Acknowledgements}

Thanks are due to SAIF, CDRI, Lucknow, and Chemistry Department, IIT-Mumbai, for providing mass analysis, and Chemistry Division, BARC for elemental analysis.

\section{Supporting Information}

Supporting Information accompanies this paper on http://www.acgpubs.org/OC 


\section{ORCID}

Abha Naveen Kumar: 0000-0003-3367-2762

Jayshree Ramkumar: 0000-0002-8621-4776

S. Chandramouleeswaran: 0000-0002-9869-3698

Sandip Kumar Nayak: 0000-0001-8974-2200

\section{References}

[1] Saadioui, M.; Bohmer, V. in Calixarenes 2001. Eds. Asfari, Z.; Bohmer, V.; Harrowfield, J.; Vicens, J. Kluwer Academic Publishers, 2001, 130-154.

[2] Asfari, Z.; Weiss, J.; Vicens, J. Double-calixarene: design, synthesis, and properties. Synlett 1993, 10, 719 725.

[3] Arduini, A.; Credi, A.; Faimani, G.; Massera, C.; Pochini, A.; Secchi, A.; Semeraro, M.; Silvi, S.; Ugozzoli, F. Self-assembly of a double calix[6]arene pseudorotaxane in oriented channels. Chem. Eur. J. 2008, 14, 98-106.

[4] Nabeshima, T.; Saiki, T.; Sumitomo, K.; Akine, S. Doubly bridged biscalix[4]arene for homotropic and heterotropic allosteric effects on ion recognition. Tetrahedron Lett. 2004, 45, 4719-4722.

[5] Garozzo, D.; Gattuso, G.; Kohnke, F. H.; Notti, A.; Pappalardo, S.; Parisi, M. F.; Pisagatti, I.; White, A. J. P.; Williams, D. J. Inclusion networks of a calix[5] arene-based exoditopic receptor and long-chain alkyldiammonium ions. Org. Lett. 2003, 5, 4025-4028.

[6] Castellano, R. K.; Rudkevich, D. M.; Rebek, J., Jr. Polycaps: reversibly formed polymeric capsules. Proc. Natl. Acad. Sci. USA 1997, 94, 7132-7137.

[7] Webber, P. R. A.; Beer, P. D.; Chen, G. Z.; Felix, V.; Drew, M. G. B. Bis(calix[4]diquinone) receptors: cesium- and rubidium-selective redox-active ionophores. J. Am. Chem. Soc. 2003, 125, 5774-5785.

[8] Budka, J.; Lhotak, P.; Stibor, I.; Michlova, V.; Sykora, J.; Cisarova, I. A biscalix[4]arene-based ditopic hard/soft receptor for $\mathrm{K}^{+} / \mathrm{Ag}^{+}$complexation. Tetrahedron Lett. 2002, 43, 2857-2861.

[9] Semwal, A.; Bhattacharya, A.; Nayak, S. K. Ultrasound mediated selective monoalkylation of 4-tertbutylcalix[6]arene at the lower rim. Tetrahedron 2002, 58, 5287-5290.

[10] Nayak, S. K.; Choudhary, M. K. Microwave-assisted synthesis of 1,3-dialkyl ethers of calix[4]arenes: application to the synthesis of cesium selective calix[4]crown-6 ionophores. Tetrahedron Lett. 2012, 53, 141-144.

[11] Ramanjaneyulu, P. S.; Kumar, A. N.; Sayi, Y. S.; Ramakumar, K. L.; Nayak, S. K.; Chattopadhyay, S. A new ion selective electrode for cesium (I) based on calix[4]arene-crown-6 compounds. J. Hazard. Mater. 2012, 205-206, 81-88.

[12] Raut, D. R.; Mohapatra, P. K.; Choudhary, M. K.; Nayak, S. K. Evaluation of two calix-crown-6 ligands for the recovery of radio cesium from nuclear waste solutions: solvent extraction and liquid membrane studies. J. Membr. Sci. 2013, 429, 197-205.

[13] Bhattacharya, S.; Nayak, S. K.; Semwal, A.; Chattopadhyay, S.; Banerjee, M. Study of host-guest interaction of [70]fullerene with substituted calix[6]arenes by absorption spectrometric method. J. Phys. Chem. A 2004, 108, 9064-9068.

[14] Bhattacharya, S.; Nayak, S. K.; Semwal, A.; Banerjee, M. Energies of charge transfer and supramolecular interactions of some mono O-substituted calix[6]arenes with [60]fullerene by absorption spectrometric method. Spectrochim. Acta Part A 2005, 61, 595-606.

[15] Bhattacharya, S.; Chattopadhyay, S.; Nayak, S. K.; Banerjee, M. Solution NMR studies of supramolecular complexes of [60]- and [70]fullerene with mono O-substituted calix[6]arene. Spectrochim. Acta Part A 2005, 62, 729-735.

[16] Ramkumar, J.; Nayak, S. K.; Maiti, B. Transport of uranyl ion across a bulk liquid membrane using calixarene and synergistic agents as carriers. J. Membr. Sci. 2002, 196, 203-210.

[17] Haino, T.; Yanase, M.; Fukazawa, Y. Fullerenes enclosed in bridged calix[5]arenes. Angew. Chem., Int. Ed. 1998, 37, 997-998.

[18] Haino, T.; Yamanaka, Y.; Araki, H.; Fukazawa, Y. Metal-induced regulation of fullerene complexation with double-calix[5] arene. Chem. Commun. 2002, 402-403.

[19] Ghosh, K.; Semwal, A.; Nayak, S. K.; Bhattacharya (Banerjee), S.; Banerjee, M. Spectrophotometric study of the supramolecular complexes of [60]- and [70]fullerenes with biscalix[6]arene and crown[4]calix[6]arene. Spectrochim. Acta Part A 2007, 66, 1122-1125. 
[20] Kanamathareddy, S.; Gutsche, C. D. Conformational characteristics of $p$-tert-butylcalix[6]arene ethers. $J$. Org. Chem. 1994, 59, 3871-3879.

[21] Santoyo-Gonzalez, F.; Torres-Pinedo, A.; Sanchez-Ortega, A. Regioselective monoalkylation of calixarenes. Synthesis of homodimer calixarenes. J. Org. Chem. 2000, 65, 4409-4414.

[22] Ciao, R.; Talotta, C.; Gaeta, C.; Margarucci, L.; Casapullo, A.; Neri, P. An oriented handcuff rotaxane. Org. Lett. 2013, 15, 5694-5697.

[23] Li, J.; Chen, Y.; Lu, X. Selective bridging of p-tert-butylcalix[6]arene with polyethylene glycol ditosylates. Tetrahedron 1999, 55, 10365-10374.

[24] Memon, S.; Yilmaz, M. Biscalixarenes: synthesis and investigation of the extraction behavior of biscalix[4] arene derivatives in a two-phase extraction system. Sep. Sci. Technol. 2001, 36, 473-486.

[25] Deligoz, H.; Yilmaz, M. Liquid-liquid extraction of transition metal cations by calixarene-based cyclic ligands. Solvent Extr. Ion Exch. 1995, 13, 19-26.

[26] Ramkumar, J.; Maiti, B.; Nayak, S. K.; Mathur, P. K. Facilitated transport of alkali metal ions across bulk liquid membrane containing phenoxy compounds as carrier. Sep. Sci. Technol. 1999, 34, 2069-2077.

[27] Casnati, A.; Jacopozzi, P.; Pochini, A.; Ugozzoli, F.; Cacciapaglia, R.; Mandolini, L.; Ungaro, R. Bridged calix[6]arenes in the cone conformation: new receptors for quaternary ammonium cations. Tetrahedron 1995, 51, 591-598.

[28] Chen, Y.; Li, J.; Xin, J.; Zhong, Z.; Gong, S.; Lu, X. Syntheses of lower-rim-1,3-crowned calix[6]arenes and their complexation abilities toward cations. Synth. Commun. 1999, 29, 705-711.

[29] Chen, Y.; Li, H. Synthesis and characterization of $p$-tert-butylcalix[6]-1,4-crown-4-2,6-crown-5, p-tertbutylcalix[6]-1,4-benzocrown-4-2,3-crown-5. Chem. Lett. 2000, 10, 1208-1209.

[30] Chen, Y.; Yang, F.; Gong, S. Molecular design and synthesis of a calix[6]crown-based lithium-selective ionophore. Tetrahedron Lett. 2000, 41, 4815-4818.

[31] Chen, Y.; Yang, F.; Lu, X. Synthesis of p-tert-butylcalix[6]-1,4-2,5-bis-crowns. Tetrahedron Lett. 2000, 41, 1571-1574.

[32] Chen, Y.; Chen, Y. Synthesis of doubly bridged p-tert-butyl-calix[6]arene containing hard and soft ion binding sites. Tetrahedron Lett. 2000, 41, 9079-9082.

[33] Yang, F.; Chen, Y. Ion complexation properties of calix[6]arene derivatives: I. 1,4-calix[6]crown-4 derivatives. Supramol. Chem. 2001, 12, 445-450.

[34] Chen, Y.; Li, H. Syntheses of novel types of calix[6]bis-crowns and related compounds. New J. Chem. 2001, 25, 340-343.

[35] Yang, F.; Chen, Y. An improved method for the synthesis of calix[6]-1,4-crown-4s. Hecheng Huaxue 2002, 10, 151-153.

[36] Ko, S. W.; Yang, Y. S.; Mun, J. H.; Park, K.-M.; Lee, S. S.; Nam, K. C. Highly cesium selective calix[6]arene receptors: synthesis, structure and cesium binding properties of calix[6]arene biscrown. Bull. Korean Chem. Soc. 2002, 23, 1379-1380.

[37] Zhang, S.; Echegoyen, L. Selective binding of aromatic amines by self-assembled monolayers of a calix[6]crown-4 derivative. Org. Lett. 2004, 6, 791-794.

[38] Galan, H.; de Mendoza, J.; Prados, P. Conformational control of calix[6]arenes through multiple bridges. Eur. J. Org. Chem. 2005, 19, 4093-4097.

[39] Rosano, H. L.; Schulman, J. H.; Weisbuch, J. B. Mechanism of the selective flux of salts and ions through nonaqueous liquid membranes. Ann. N. Y. Acad. Sci. 1961, 92, 457-469.

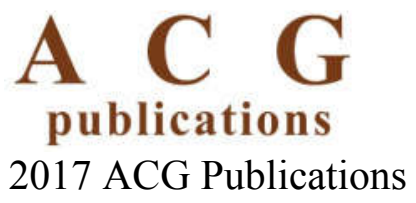

